\title{
Subcritical Water Treatment for Producing Seasoning From Semidried Isada Krill
}

\section{$\operatorname{AUTHOR}(S)$ :}

Koomyart, Intira; Nagamizu, Hironori; Khuwijitjaru, Pramote; Kobayashi, Takashi; Shiga, Hirokazu; Yoshii, Hidefumi; Adachi, Shuji

\section{CITATION:}

Koomyart, Intira ...[et al]. Subcritical Water Treatment for Producing Seasoning From Semidried Isada Krill. Journal of Food Process Engineering 2014, 37(6): 567-574

\section{ISSUE DATE:}

2014-09-03

URL:

http://hdl.handle.net/2433/198296

\section{RIGHT:}

This is the peer reviewed version of the following article: Koomyart, I., Nagamizu, H., Khuwijitjaru, P., Kobayashi, T., Shiga, H., Yoshii, H. and Adachi, S. (2014), Subcritical Water Treatment for Producing Seasoning From Semidried Isada Krill. Journal of Food Process Engineering, 37: 567-574, which has been published in final form at

http://dx.doi.org/10.1111/jfpe.12110. This article may be used for non-commercial purposes in accordance with Wiley Terms and Conditions for Self-Archiving.; 許諾条件により本文ファイルは2015-09-03に公開.; This is not the published version. Please cite only the published version.; この論文は出版社版でありません。引用の際には出版社版をご確認ご 利用ください。 
Running Head: SEASONING FROM SEMIDRIED ISADA KRILL

\title{
SUBCRITICAL WATER TREATMENT FOR PRODUCING SEASONING FROM SEMI-DRIED ISADA KRILL
}

INTIRA KOOMYART ${ }^{1}$, HIRONORI NAGAMIZU ${ }^{1}$, PRAMOTE KHUWIJITJARU ${ }^{2}$, TAKASHI KOBAYASHI $^{1}$, HIROKAZU SHIGA ${ }^{3}$, HIDEFUMI YOSHII ${ }^{3}$, and SHUJI ADACHI ${ }^{1,4}$

${ }^{1}$ Division of Food Science and Biotechnology, Graduate School of Agriculture, Kyoto University, Kyoto 606-8502, Japan

${ }^{2}$ Department of Food Technology, Faculty of Engineering and Industrial Technology, Silpakorn University, Nakhon Pathom 73000, Thailand

${ }^{3}$ Department of Applied Biological Science, Faculty of Agriculture, Kagawa University, Kagawa 761-0795, Japan

${ }^{4}$ Corresponding author

TEL: +81-75-753-6286

FAX: +81-75-753-6285

E-MAIL: adachi@kais.kyoto-u.ac.jp

\begin{abstract}
Semi-dried isada krill (Euphausia pacifica) was treated with boiling water and subcritical water at $100-240^{\circ} \mathrm{C}$ for $10 \mathrm{~min}$ with a semi-dried krill to water ratio of $8 / 52 \mathrm{w} / \mathrm{v}$ to produce seasoning. The protein concentration, lipid content, and odor concentration of the extract increased on increasing the treatment temperature. The highest protein content of the extract (0.047-0.049 $\mathrm{kg} / \mathrm{kg}$-extract) was obtained by subcritical water treatment at 180 or $200^{\circ} \mathrm{C}$. Compounds with lower molecular mass were detected in the extracts derived from subcritical water treatment at
\end{abstract}


temperatures higher than $160^{\circ} \mathrm{C}$. The extract prepared by subcritical water treatment at 160 and $180^{\circ} \mathrm{C}$ received the high score in the flavor preference test by a group of panelists. Treatment at temperatures lower and higher than $160-180^{\circ} \mathrm{C}$, respectively, conferred undesirable fishy and smoky or burnt odors to the extracts and residues.

KEYWORDS: flavor preference, isada krill, seasoning, subcritical water

\section{PRACTICAL APPLICATION}

Although isada krill is abundant in the Sanriku coast, Japan, its usage is limited to low-valueadded products such as animal and aquaculture feeds. However, we found that subcritical water treatment of the krill produces an extract solution and a solid residue, both of which possess good flavor and proffer a great prospective for use as seasoning. Establishment of a method for using the krill as a raw material for seasoning with shrimp-like flavor would increase the value of the krill as a food resource for human consumption.

\section{INTRODUCTION}

Krill is a small shrimp-like crustacean and is found in all oceans. It plays an important role as a food for larger animals in the oceanic food chain (Gascon and Werner 2005). Isada krill (Euphausia pacifica) is the Pacific krill found mainly around the Sanriku coast, Japan. Approximately 70,000 t of isada krill is harvested annually for use in animal feed, aquaculture, and human consumption in Japan (Nicol and Endo 1997).

Most of the harvested krill is used as animal feed. Krill meal is utilized as a protein source in the feed of a number of marine organisms such as salmon, trout (Budzinski et al. 1985), red sea bream (Shimizu et al. 1990), yellow tail, and shrimp (Nunes et al. 2010). Moreover, krill extract provides a supplement oil rich in eicosapentaenoic acid (EPA), docosahexanoic acid (DHA), astaxanthin, and essential amino acids (Tou et al. 2007). However, krill is not used extensively for human consumption, despite the fact that it is a promising food resource that is widely available and high in nutritional value.

Subcritical water is water that maintains its liquid state in the temperature range $100-374^{\circ} \mathrm{C}$ under pressurized conditions. The extraction capacity of subcritical water is contingent on its characteristic properties of low relative dielectric constant and high ion product (Tavakoli and 
Yoshida 2006; Yoshida et al. 1999; Pourali et al. 2009). Recently, the hydrolysis of organic wastes or unused resources with subcritical water has gained prominence as a potential means of converting such matter to usable substances such as saccharides, fatty acids, phenolic compounds, amino acids, and proteins. Subcritical water treatment has been applied to rice bran (Pourali et al. 2009; Wiboonsirikul et al. 2007), poultry waste (Zhu et al. 2010), squid viscera (Uddin et al. 2010), and Baker's yeast cells (Lamoolphak et al. 2006) to produce useful substances.

In this context, subcritical water treatment of isada krill is investigated herein for the production of seasoning with shrimp-like flavor.

\section{MATERIALS AND METHODS}

\section{Materials}

Semi-dried isada krill (Euphausia pecifica) was purchased from Kinoya Ishinomaki Suisan (Miyagi, Japan). The krill contained 0.33 g/g (w.b.) of water and 0.0308 g/g (w.b.) of lipid. The semi-dried krill samples were packed in 10 -g vacuum aluminum foil bags and kept at $-20^{\circ} \mathrm{C}$ prior to use. Diethyl ether and bovine serum albumin (BSA, 99\% purity) were purchased from Wako Pure Chemical Industries (Osaka, Japan). Folin-Ciocalteu reagent was purchased from ICN Biochemicals (OH, USA). Other reagents were of analytical grade.

\section{Boiling and Subcritical Water Treatment of Isada}

Eight gram of the semi-dried krill and $52 \mathrm{~mL}$ of distilled water were loaded into a 100-mL pressure-resistant vessel (Taiatsu Techno, Osaka, Japan) and heated to the desired temperature $\left(100-240^{\circ} \mathrm{C}\right)$ for 10 min using a mantle heater (200 W, Heater Engineer, Tokyo, Japan) and a TXN 700B thermo-controller (As One, Osaka, Japan). As a control treatment (boiling), the krill (24 g) was combined with $156 \mathrm{~mL}$ of distilled water in an open aluminum pot and boiled for 10 min. After subcritical water treatment or boiling, the vessel or aluminum pot was immediately cooled in an ice-water bath. The extract was filtered through an Advantec No. 2 filter paper (Toyo Roshi, Tokyo, Japan) under reduced pressure. All the wet residue was packed in a nylon sheet bag $(25 \times 100 \mathrm{~mm})$ and was pressed at 7.86 MPa using a hydraulic press. The obtained liquid was pooled with the filtered extract. Boiling and subcritical water treatments were 
performed in triplicate.

\section{Moisture and Solid Contents}

The residue and extract obtained by pressing were immediately subjected to the analyses of the moisture and solid contents. The moisture content of the krill residue was determined by the oven-drying method (Ileleji et al. 2010). The sample was dried in a hot-air oven at $135^{\circ} \mathrm{C}$ for $2 \mathrm{~h}$. The solid content of the krill extract was also determined by the same method.

\section{Lipid Content}

The lipid content in the krill extract or residue was determined by Soxhlet extraction (AOAC 2006). Prior to analysis, the residue was dried in the dry oven at $105^{\circ} \mathrm{C}$ for $4 \mathrm{~h}$ and ground. The lipid in extract $(1.0 \mathrm{~g})$ dehydrated with sodium sulfate $(2.0 \mathrm{~g})$ or residue powder (1.0 g) was extracted with diethyl ether $(100 \mathrm{~mL})$ in a conventional Soxhlet apparatus for $10 \mathrm{~h}$. The remaining solvent was removed by drying in a hot air oven at $90^{\circ} \mathrm{C}$ until constant weight was attained.

\section{Protein Content}

The protein content of the krill extract was determined by the Lowry-Folin method (Lowry et al. 1951). Briefly, the krill extract was centrifuged at $6000 \mathrm{rpm}(4270 \times \mathrm{g})$ for $20 \mathrm{~min}$. The appropriately diluted supernatant $(0.4 \mathrm{~mL})$ was mixed with Lowry reagent $(2 \mathrm{~mL})$ and 50\% (w/v) of Folin reagent $(0.2 \mathrm{~mL})$ and left at room temperature for $30 \mathrm{~min}$. The absorbance of the mixture at $750 \mathrm{~nm}$ was measured for the determination of the protein content. BSA solutions with concentrations ranging from 100 to $500 \mathrm{mg} / \mathrm{L}$ were used to obtain a calibration curve.

\section{Freezing Point Depression}

The krill extract was filtered through an Advantec No. 2 filter paper. The extract would contain much kind of molecules at different concentrations. As an indication of the overall molality of the extract, its freezing point depression was measured using an osmometer (OM802, Vogel, Kevelaer, Germany).

\section{Size Exclusion Chromatography}


The extract was subjected to size-exclusion chromatography (SEC) using an HPLC system (SPD-10A pump and SPD-10A UV-Vis detector, Shimadzu, Kyoto, Japan) equipped with a YMC-pack Diol-120 column (500 × 0.8 mm i.d., YMC, Kyoto, Japan) at ambient temperature. Distilled water (flow rate: $1.0 \mathrm{~mL} / \mathrm{min}$ ) was used as the mobile phase. The krill extract was centrifuged at $6000 \mathrm{rpm}$ for $20 \mathrm{~min}$ and filtered through a $0.45-\mu \mathrm{m}$ syringe filter before injecting $17 \mu \mathrm{L}$ of the sample into the column. The elution profile was monitored at the wavelength of 280 $\mathrm{nm}$. The elution time was related to molecular mass using the calibration curve provided by the manufacturer (YMC general catalog 2007/2008, YMC, Kyoto, Japan).

\section{Odor Concentration}

An odor concentration meter (XP-329IIIR, Cosmos, Tokyo, Japan) was used to measure the concentrations of volatile compounds from the krill extracts and residues. The instrument detects odor molecules using a tin dioxide thermal semiconductor sensor (Watts 1992; Sweeten et al. 1999). The krill extract ( $1 \mathrm{~mL})$ or krill residue $(1 \mathrm{~g})$ was placed in a 5-mL amber glass bottle. The bottle was capped and incubated at $25^{\circ} \mathrm{C}$ in a water bath for $10 \mathrm{~min}$. The cap was opened at the preset incubation time and the electronic probe was then immediately placed on the opening of the bottle until a constant signal was attained. The odor concentration was expressed as odor unit/mL of head space.

\section{Flavor Preference Evaluation}

The extract $(1 \mathrm{~mL})$ or residue $(1 \mathrm{~g})$, placed in an amber bottle, was presented to 10 untrained panelists for flavor preference scoring. Flavor characteristics (shrimp-like, fishy, smoky and burnt flavor) of the samples were evaluated as the overall preference score using the 5-point hedonic scale (-2: dislike very much, -1: dislike, 0: neither like nor dislike, +1: like, and +2: like very much). The scores were presented as the mean \pm SD and analyzed the difference by analysis of variance (ANOVA) using SAS version 9.0 (SAS Institute, Cary, NC) for randomized complete block design (RCBD) at the $p<0.05$ level.

\section{RESULTS AND DISCUSSION}

\section{Appearance}


Semi-dried isada krill was boiled or treated with subcritical water in the temperature range 100$240^{\circ} \mathrm{C}$ for $10 \mathrm{~min}$. Figure 1 shows the photographs of the krill extracts and residues treated at various temperatures. The krill extracts obtained by boiling and subcritical water treatment at $100-140^{\circ} \mathrm{C}$ were light yellow, whereas the extract prepared at $160^{\circ} \mathrm{C}$ was reddish-yellow. The extracts prepared at higher temperatures gradually became brownish-yellow, and the extract prepared at $240^{\circ} \mathrm{C}$ was dark brown. The residues from subcritical water treatment at low temperatures were reddish-pink, similar to the residue of boiled krill. The residue from treatment at $160^{\circ} \mathrm{C}$ was light brown, and a dark brown residue was obtained from treatment at $240^{\circ} \mathrm{C}$. Astaxanthin is a natural carotenoid found in krill. In krill, it is normally conjugated with chromoprotein; this conjugate is degraded by cooking, leading to the development of a reddish color in cooked krill (Goodwin 1960). These results indicate that more astaxanthin is extracted from the krill by subcritical water treatment at higher treatment temperatures. The dark brown color obtained with higher treatment temperatures results from the products of browning reactions such as the Maillard reaction or caramelization of sugars (Plaza et al. 2010).

\section{Yields of Krill Extract and Residue}

Boiling and subcritical water treatment of semi-dried krill followed by hydraulic pressing yielded two fractions: aqueous krill extract and solid krill residue. Figure 2 shows the yields of the krill extract and residue obtained at different treatment temperatures. The overall yield, which was defined as a sum in yield of extract and residue, obtained by boiling was approximately 0.75 $\mathrm{kg} / \mathrm{kg}$-mixture, because some water was lost by evaporation during boiling using the open pot. The yield of the residue from the boiling treatment was $0.20 \mathrm{~kg}$-wet residue/kg-mixture, whereas the yield obtained from the subcritical water treatment decreased with increasing treatment temperature. Notably, the yield declined significantly at treatment temperatures higher than $140^{\circ} \mathrm{C}$. The yield of the extract increased at higher treatment temperatures. The respective increase and decrease of the yield of the extract and residue with increasing temperature indicate that subcritical water promotes the extraction and decomposition of components more efficiently at higher temperatures.

\section{Properties of Krill Extracts}

The total solid, lipid, and protein contents, the freezing point, and molecular mass distribution 
were determined for the extracts prepared by boiling and subcritical water treatment at various temperatures. The lipid content of the extract obtained by boiling using the open pot $(0.0053$ $\mathrm{kg} / \mathrm{kg}$-extract) was similar to that obtained by treatment at $100^{\circ} \mathrm{C}$ using the closed vessel $(0.0068$ $\mathrm{kg} / \mathrm{kg}$-extract). The lipid content increased gradually with increasing temperature, and the highest lipid content of $0.0121 \mathrm{~kg} / \mathrm{kg}$-extract was achieved by treatment at $240^{\circ} \mathrm{C}$ (Fig. 3). This is because subcritical water has a higher capacity to dissolve lipophilic substances because of its lower polarity (Khuwijitjaru et al. 2002). In addition, the lower surface tension and viscosity of subcritical water at higher temperature may facilitate extraction under subcritical conditions (Pourali et al. 2009).

Figure 3 also shows the protein content of the extracts obtained by boiling and subcritical water treatment at various temperatures. The protein contents of the extracts prepared at $100^{\circ} \mathrm{C}$ using the open pot and closed vessel were similar. The protein contents of the extracts obtained from subcritical water treatment increased with increasing treatment temperature. The highest protein content of $0.047-0.049 \mathrm{~kg} / \mathrm{kg}$-extract was obtained at $180-200^{\circ} \mathrm{C}$; the protein content of the extract decreased at higher temperatures. These results are consistent with those of previous studies. For example, Wiboonsirikul et al. (2007) reported that the protein content of rice bran extract obtained by subcritical water treatment increased as the treatment temperature was increased from 50 to $200^{\circ} \mathrm{C}$, with a marked decrease at the treatment temperature $250^{\circ} \mathrm{C}$. The increase in the protein content of the extracts is indicative of the hydrolysis of proteinaceous substances in the krill to soluble peptides and amino acids (Yoshida et al. 1999). The decrease of in protein content of the extract at 220 and $240^{\circ} \mathrm{C}$ indicated that the proteinaceous components were further decomposed or converted to other products. For example, amino acids may react with carbohydrates to form brown products via Maillard reaction.

The total solid content of the krill extract increased with increasing treatment temperature and reached a constant value of $0.073 \mathrm{~kg} / \mathrm{kg}$-extract (Fig. 3). The freezing points of the subcritical water extracts decreased with increasing solid content. The total solid was almost constant between 200 and $240^{\circ} \mathrm{C}$, but the freezing point of the extract decreased at those temperatures. These facts indicate that molecule in the extract would be converted to small ones at high temperature. The freezing point of the extract obtained by boiling was significantly lower than those of the extracts derived from subcritical treatment at various temperatures (except at $240^{\circ} \mathrm{C}$ ), because the solid content of the extract obtained by boiling was higher than those of the extracts 
derived from subcritical water treatment owing to evaporation of water during boiling.

\section{Molecular Mass Distributions}

SEC was used to qualitatively determine the molecular mass distribution of the extracts (Fig. 4). Boiling and subcritical water treatment at $100-140^{\circ} \mathrm{C}$ led to similar chromatograms, i.e., a group of peaks was present at retention times of 6-13 min which corresponded to molecular mass of $10^{6}-10^{8} \mathrm{Da}$ and another large peak was observed at $19.3 \mathrm{~min}\left(10^{4} \mathrm{Da}\right)$. For subcritical water treatment at $\geq 160^{\circ} \mathrm{C}$, the intensity of the group of higher molecular mass $\left(10^{6}-10^{8} \mathrm{Da}\right)$ became significantly higher because of the increased solid content of the extracts (Fig. 3). In addition, several peaks of molecular mass of $10^{4}-10^{6}$ were observed; some small peaks of molecular mass of $10 \mathrm{kDa}$ were also detected after $20 \mathrm{~min}$. These results indicate that a greater number of lowermolecular-mass (molecular mass $<10 \mathrm{kDa}$ ) compounds were produced at higher temperatures, although the compounds were not conclusively identified.

\section{Properties of Krill Residues}

Moisture content analysis of the pressed residues was performed via the hot-air oven method. The moisture contents of the residues obtained at $100^{\circ} \mathrm{C}$ using the open pot and closed vessel were almost the same (Fig. 5). The moisture content of the residues obtained by subcritical water treatment at $100-140^{\circ} \mathrm{C}$ was ca. $0.21-0.28 \mathrm{~kg}-\mathrm{H}_{2} \mathrm{O} / \mathrm{kg}$-dried residue; the value gradually decreased with increasing treatment temperature. This is ascribed to the destruction of the cellular structures of krill by heat and pressure, resulting in the loss of water-binding capability.

The lipid contents of the dried krill residues were determined after hot-air oven drying (Fig. 5), because the lipid content of the residue obtained using the open pot was almost the same as that of the residue prepared at $100^{\circ} \mathrm{C}$ using the closed vessel. The lipid remained in the dried residues obtained by using subcritical water at $100-240^{\circ} \mathrm{C}(0.053-0.161 \mathrm{~kg} / \mathrm{kg}$-dried residue). Although many substances were extracted into the extract solution during subcritical water treatment at high temperature, the lipid would remain more in the solid residue than hydrophilic substances. The lipid content was defined as kg-lipid/kg-dry residue. Therefore, the higher lipid content in the residue treated at higher temperature would be ascribed to less amount of the dry residue.

\section{Odor Concentration and Flavor Preference}


The flavor of the extract and residue is an important characteristic for their use as seasoning. The suitability of the extract and residue as seasoning was analyzed on the basis of odor concentration measurement and flavor preference evaluation. The odor intensity increased gradually with increasing treatment temperature for both the extract and residue (Fig. 6(A)) with a more pronounced increase in the case of the extract. This might indicate that the volatile compounds are easily dissolved in water.

Figure 6(B) shows the flavor preference score of the extracts and residues prepared at different temperatures. The extracts and residues were presented to 10 Japanese panelists who scored and described the characteristics of the flavor of each sample. Boiling using the open pot and treatment at $100^{\circ} \mathrm{C}$ using the closed vessel imparted a fishy odor to the samples accompanied by a low preference score. Giogios et al. (2013) evaluated the volatile compounds of the shrimp solution extracted via simultaneous steam distillation, and showed that the extract contained sulfur-compounds and amines that impart a fishy odor. The highest preference scores, which reflected the property of shrimp-like flavor, were given for the extracts and residues obtained at 160 and $180^{\circ} \mathrm{C}$. The Maillard reaction is inextricably linked to the desirable flavor and color characteristics of thermally processed food (Mottram 2007). The Maillard reaction during the thermal treatment results in the formation of many volatile compounds such as aliphatic compounds, alcohols, ketones, and pyrazine (Ba et al. 2012). The low preference scores for the severe treatments at $200-240^{\circ} \mathrm{C}$ may be ascribed to the detection of smoky and burnt flavors. It is possible that the subcritical water treatment at elevated temperature produced an off-flavor because of protein hydrolysis. Therefore, the extract obtained by subcritical water treatment at 160 and $180^{\circ} \mathrm{C}$ is deemed suitable for use as food seasoning.

\section{CONCLUSIONS}

The protein content, freezing point depletion, and odor preference score of krill extracts and residues prepared by boiling and subcritical water treatment at various temperatures differed on the basis of the conditions employed. There were tendencies that high protein content and flavor preference score were achieved by subcritical water treatment at 160 and $180^{\circ} \mathrm{C}$. Therefore, we concluded that the subcritical water treatment at 160 and $180^{\circ} \mathrm{C}$ for 10 min produces a krill extract and residue that can be used as seasoning. 


\section{ACKNOWLEDGMENTS}

This study was performed under the project "The Creation of Innovative Technology for Marine Products Industry” of the Program for Revitalization Promotion, Japan Science and Technology Agency (JST).

\section{REFERENCES}

AOAC, 2006. Official methods of analysis of AOAC International, 18th Ed. AOAC International, Gaithersburg, MD.

BA, H.V., HWANG, I., JEONG, D. and TOUSEEF, A. 2012. Principle of meat aroma flavors and future prospect. In Latest Research into Quality Control, (I. Akyar, eds.) URL: http://www.intechopen.com/books/latest-research-into-quality-control/principle-of-meat-aromaflavors-and-future-prospect

BUDZINSKI, E., BYKOWSKI, P. and DUTKIEWICZ, D. 1985. Possibilities of processing and marketing of product made from Antarctic krill. FAO Fisheries Technical Paper. 268, p.46 GASCON, V. and WERNER, R. 2005. Antarctic krill: A case study on the ecosystem implication of fishing. Antarctic and Southern Ocean Coalition. Argentina, p.30 [online] URL: http://www.lighthouse-foundation.org/fileadmin/LHF/PDF/Antarctic-krill-LF_EN.pdf GIOGIOS, I., KALOGEROPOULOS, N. and GRIGORAKIS, K. 2013. Volatile compounds of some popular Mediterranean seafood species. Mediterranean Marine Science. 14(2), 343-352. GOODWIN, T.W. 1960. Biochemistry of pigments. In The Physiology of Crustacea. Vol. 1. Metabolism and growth, (T.H. Waterman, eds.) pp.101-140, Academic Press, New York. ILELEJI, K.E., GRACIA, A.A., KINGSLY, A.R.P. and CLEMENTSON, C.L. 2010. Comparison of standard moisture loss-on-drying methods for determination of moisture content of corn distillers grains with solubles. Journal of AOAC International. 93 (3), 825-832. KHUWIJITJARU, P., ADACHI, S. and MATSUNO, R. 2002. Solubility of saturated fatty acids in water at elevated temperatures. Bioscience, Biotechnology, and Biochemistry. 66 (8), 17231726.

LAMOOLPHAK, W., GOTO, M., SASAKI, M., SUPHANTHARIK, M. MUANGNAPOH, C., PROMMUAG, C. and SHOTIPRUK, A. 2006. Hydrothermal decomposition of yeast cells for production of proteins and amino acids. Journal of Hazardous Materials. 137, 1643-1648. LOWRY, O.H., ROSEBROUGH, N. J., LEWIS FARR, A. and RANDALL, R.J. 1951. Protein 
measurement with the Folin phenol reagent. Journal of Biochemical Chemistry. 265-275. MOTTRAM, D.S. 2007. The Maillard reaction: source of flavor in thermally processed foods. In Flavours and Fragrances, (R. G. Berger, eds.) pp. 269-283, Springer-Verlag: Berlin, Germany. NICOL, S. and ENDO, Y. 1997. Krill fisheries of the world; North Pacific krill. In Food and Agriculture Organization of the United Nations. FAO Fisheries Technical paper. 367, 100 pp. Rome.

NUNES, A.J.P., SA, M.V.C. and SABRY-NETO, H. 2010. Krill meal use reduces other costly ingredients in shrimp study diets. The Global Aquaculture Advocate. 13, 36-38.

PLAZA, M., AMIGO, B.M., CASTILLO, M.D., IBANEZ, E. and HERRERO, M. 2010. Facts about the formation of new antioxidants in natural samples after subcritical water extraction. Food Research International. 43(10), 2341-2348.

POURALI, O., ASGHARI, F.S. and YOSHIDA, H. 2009. Sub-critical water treatment of rice bran to produce valuable materials: A review. Food Chemistry. 155, 1-7.

SHIMIZU, C., IBRAHIM, A., TOKOROA, T. and SHIRAKAWA, Y. 1990. Feeding stimulation in sea bream, Pagrus major, fed diets supplemented with Antarctic krill meals. Aquaculture. 89, 43-53.

SWEETEN, J.M., COLE, N.A., PARKER, D.B. and AUVERMANN, B.W. 1999. Detecting and reducing ammonia emissions from cattle feedlots and dairies: A review. International workshop on atmospheric nitrogen compounds II: Emissions, Transport, Transformation, Deposition, and Assessment. June 7-9, 1999. Chapel Hill, NC.

TAVAKOLI, O. and YOSHIDA, H. 2006. Conversion of scallop viscera wastes to valuable compounds using sub-critical water. Green Chemistry. 8, 100-106.

TOU, J.C., JACZYNSKI, J. and CHEN, Y. 2007. Krill for human consumption: nutritional value and potential health benefits. Nutrition Review. 65 (2), 63-77.

UDDIN, M. S., AHN, H., KISHIMURA, H. and CHUN, B. 2010. Production of valued materials from squid viscera by subcritical water hydrolysis. Journal of Environmental Biology. 31(5), 675-679.

WATTS, P.J. 1992. Odour measurement at a Queensland Feedlot. In: Odour update 92: Proceedings of a workshop on agricultural odours. MRC Report DAQ 64/24, Department of Primary Industries, Toowoomba, QLD. pp. 71-91.

WIBOONSIRIKUL, J., KIMURA, Y., KADOTA, M., MORITA, H., TSUNO, T. and ADACHI, 
S. 2007. Properties of extracts from defatted rice bran by its subcritical water treatment. Journal of Agricultural and Food Chemistry. 55, 8759-8765.

YOSHIDA, H., TERASHIMA, M. and TAKAHASHI, Y. 1999. Production of organic acids and amino acids from fish meat by sub-critical water hydrolysis. Biotechnology Progress. 15(6), 1090-1094.

ZHU, G.Y., ZHU, X., WAN, X.L., FAN, Q., MA, Y.H., LIU, X.L., SHEN, Y.J. and JIANG, J.H. 2010. Hydrolysis technology and kinetics of poultry waste to produce amino acid in subcritical water. Journal of Analytical and Applied Pyrolysis. 88 (2), 187-191. 


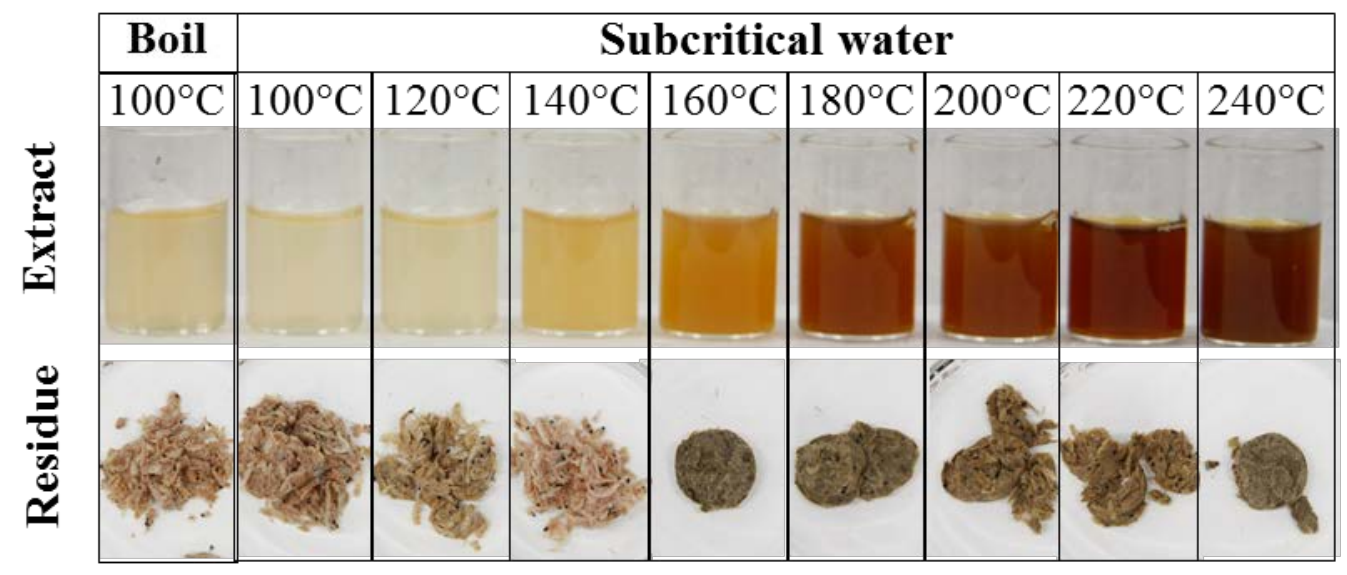

FIG. 1. APPEARANCE OF EXTRACTS AND RESIDUES PREPARED BY BOILING AND SUBCRITICAL WATER TREATMENT AT VARIOUS TEMPERATURES. 


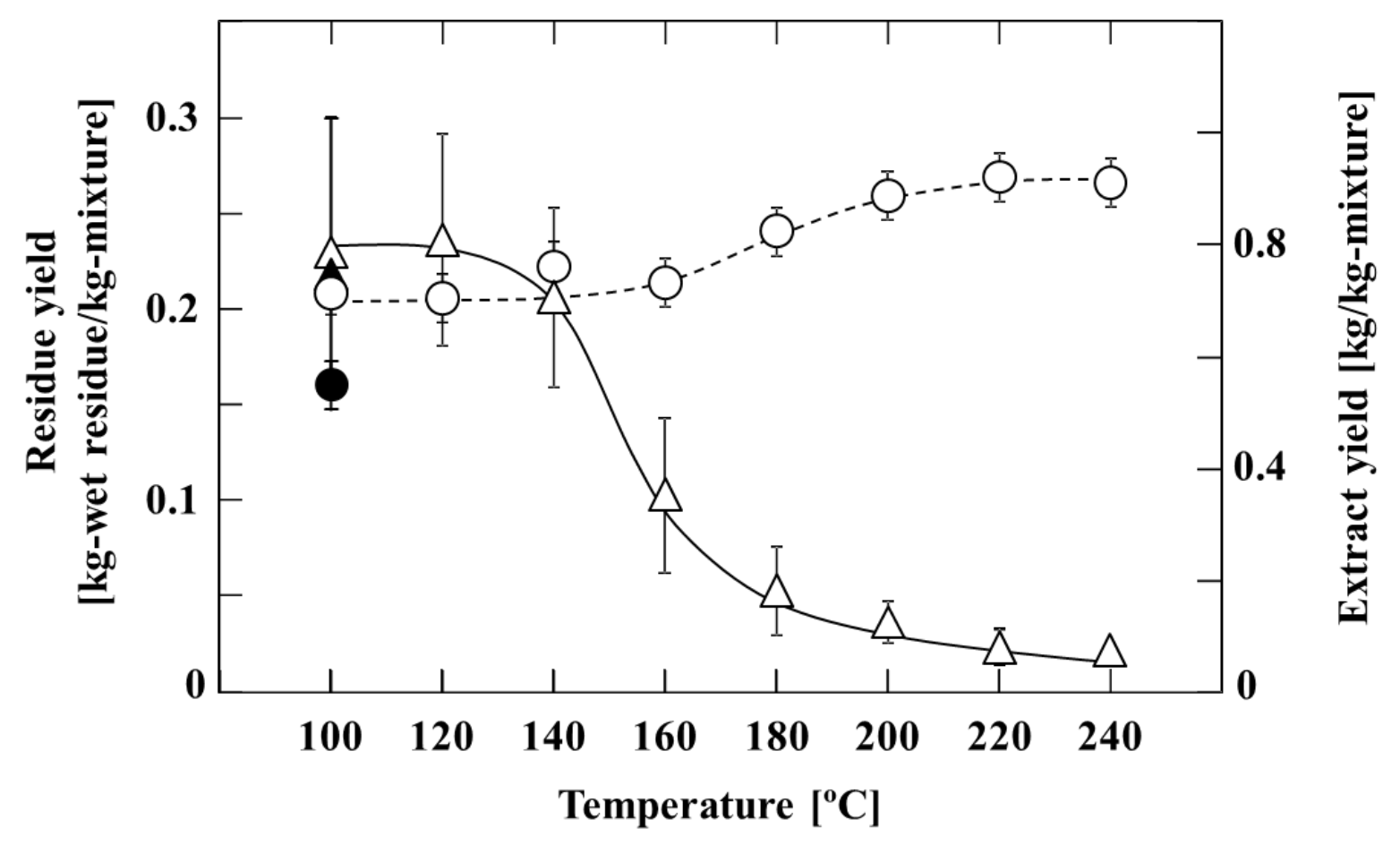

FIG. 2. YIELDS OF RESIDUE $(\boldsymbol{\Delta}, \triangle)$ AND EXTRACT $(\bullet, \bigcirc)$ OF ISADA KRILL OBTAINED BY BOILING (CLOSED SYMBOLS) AND SUBCRITICAL WATER TREATMENT AT VARIOUS TEMPERATURES (OPEN SYMBOLS). 


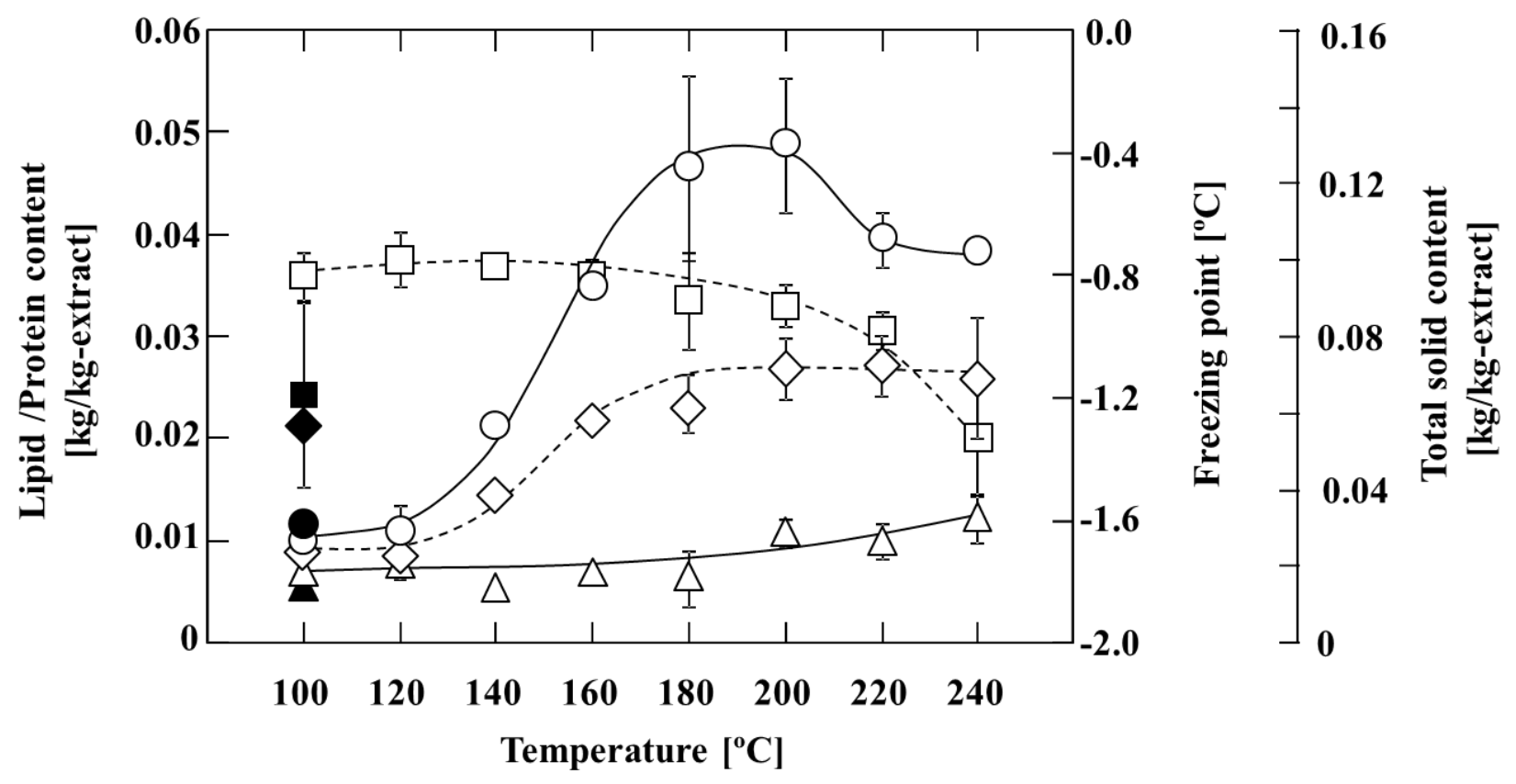

FIG. 3. $\operatorname{LIPID} \operatorname{CONTENT}(\boldsymbol{\Delta}, \triangle)$, PROTEIN CONTENT $(\boldsymbol{\bullet}, \bigcirc)$, FREEZING POINT $(\boldsymbol{\square}, \square)$, AND TOTAL SOLID CONTENT $(\diamond, \diamond)$ OF ISADA KRILL EXTRACT PREPARED BY BOILING (CLOSED SYMBOLS) AND SUBCRITICAL WATER TREATMENT AT VARIOUS TEMPERATURES (OPEN SYMBOLS). 


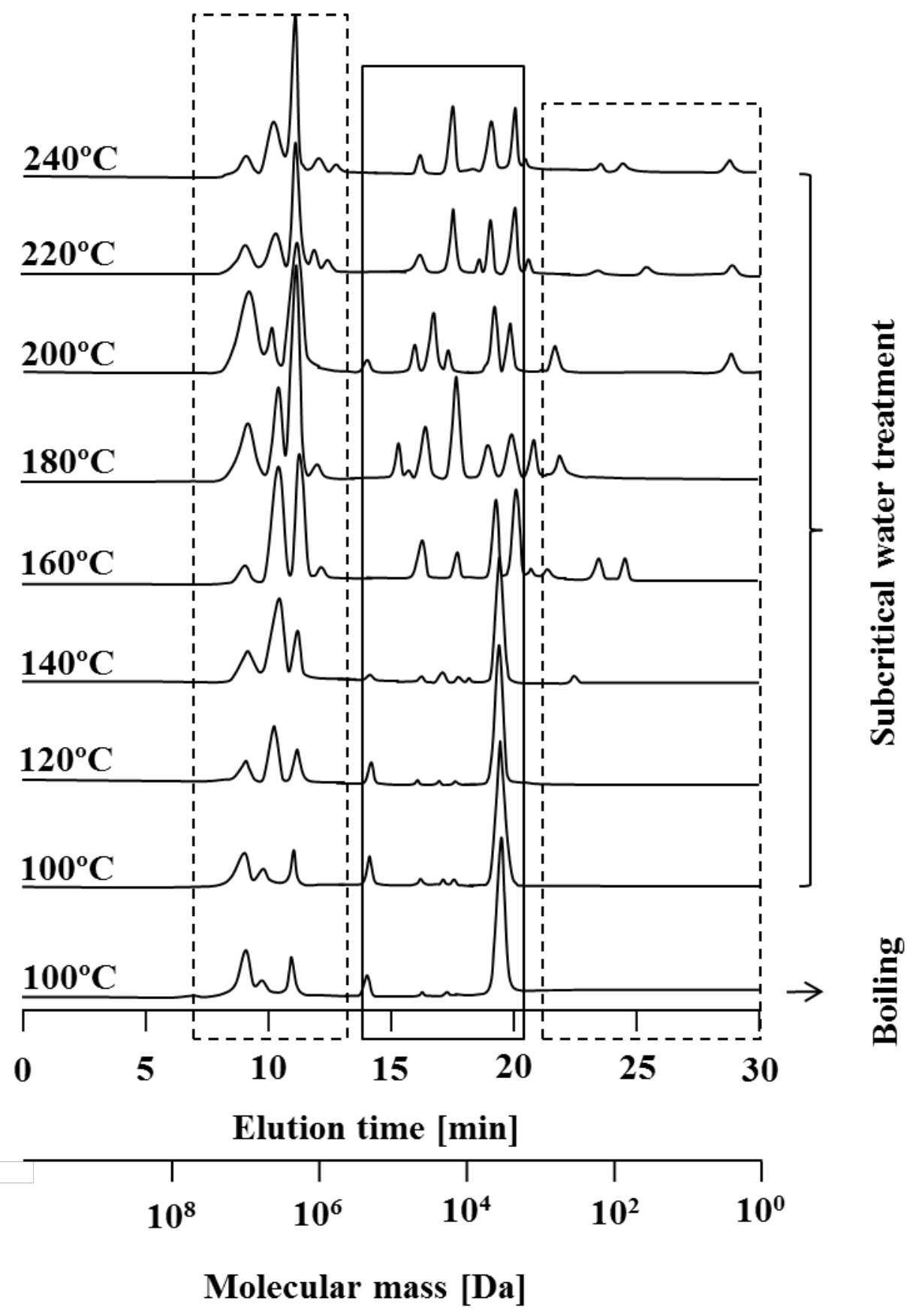

FIG. 4. SIZE-EXCLUSION CHROMATOGRAMS OF KRILL EXTRACTS OBTAINED BY BOILING AND SUBCRITICAL WATER TREATMENT AT VARIOUS TEMPERATURES. 


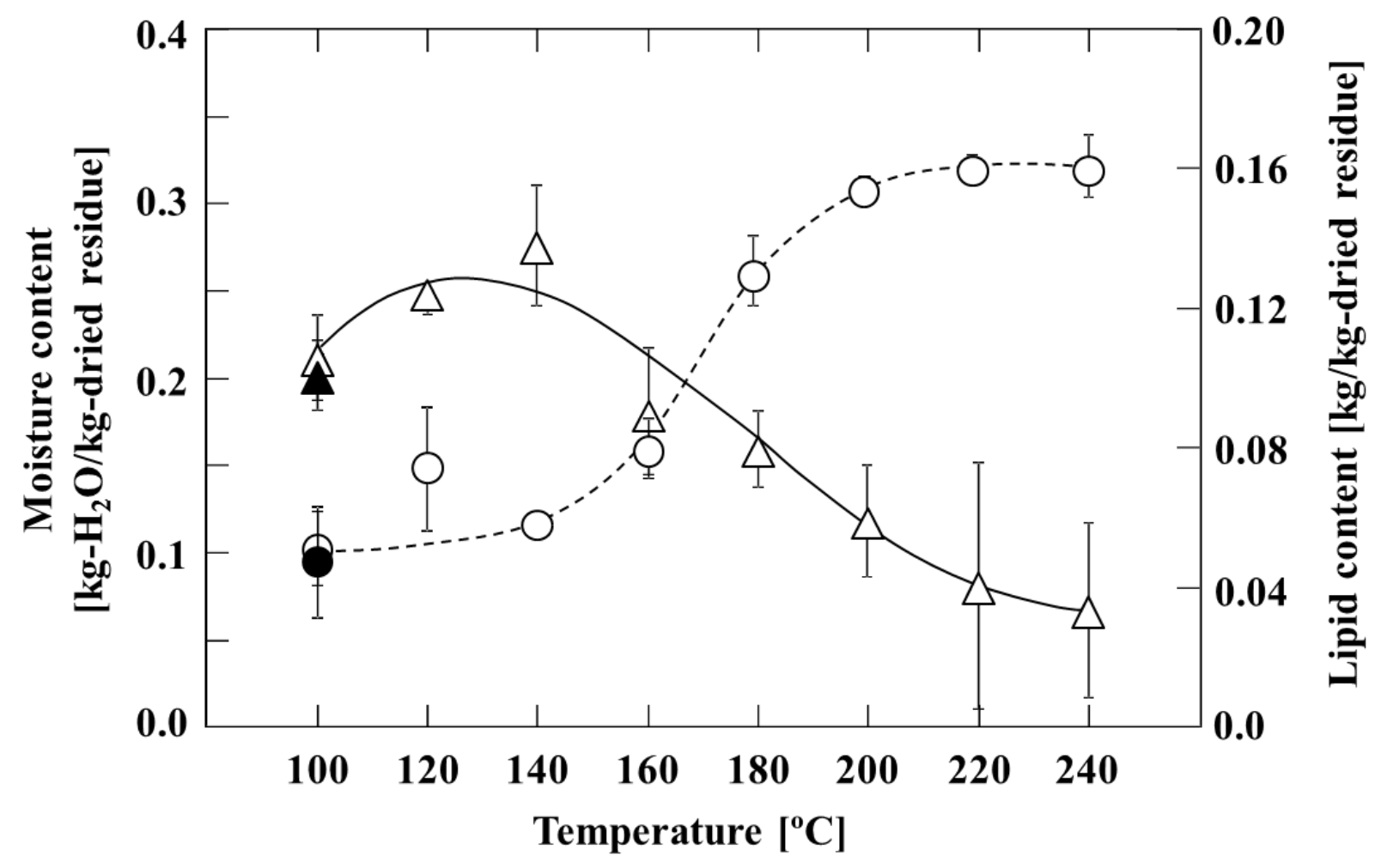

FIG. 5. MOISTURE CONTENT $(\boldsymbol{\Delta}, \triangle)$ AND LIPID $\operatorname{CONTENT}(\boldsymbol{\bullet}, \bigcirc)$ OF ISADA KRILL RESIDUES OBTAINED BY BOILING (CLOSED SYMBOLS) AND SUBCRITICAL WATER TREATMENT AT VARIOUS TEMPERATURES (OPEN SYMBOLS). 


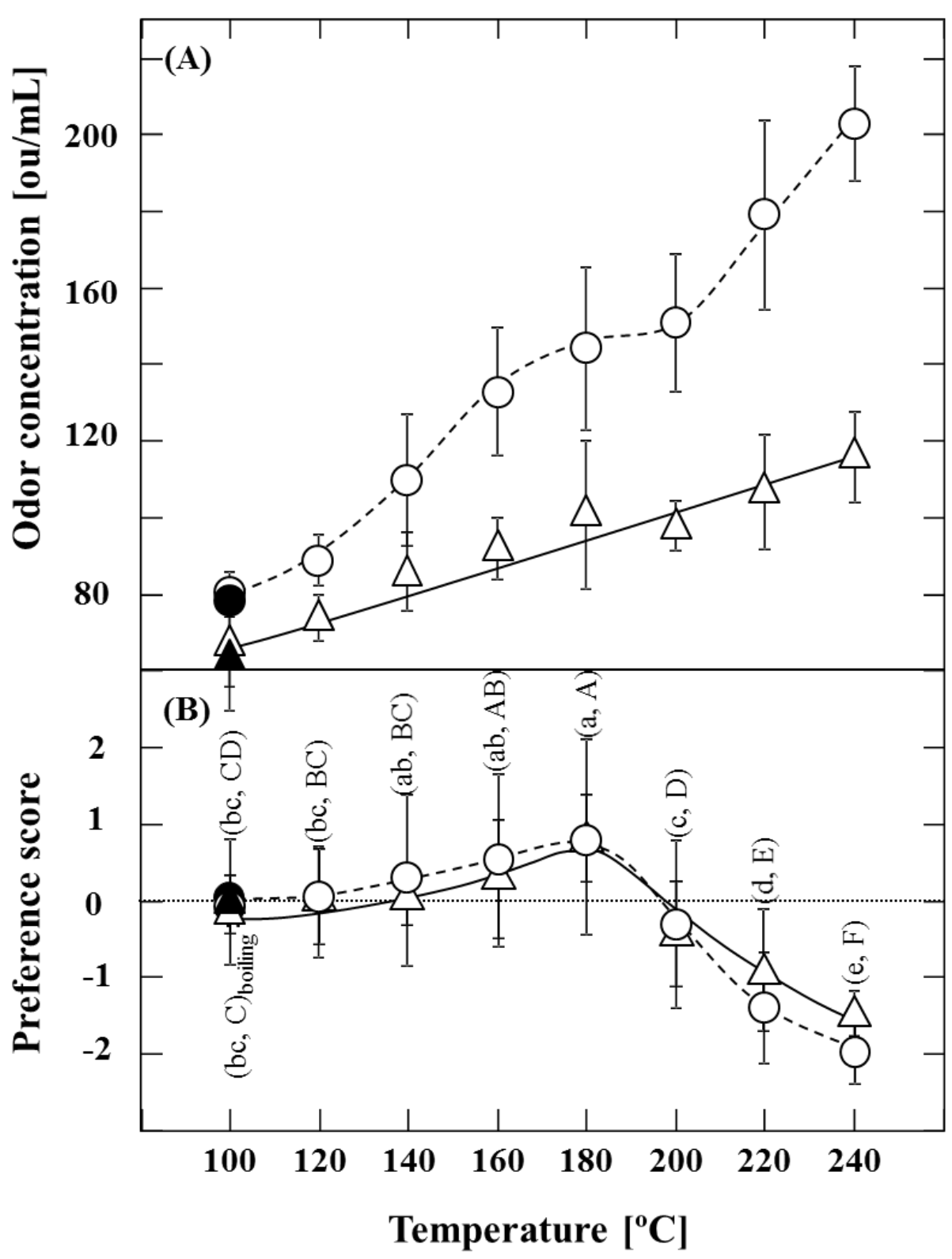

FIG. 6. (A) ODOR CONCENTRATION AND (B) FLAVOR PREFERENCE SCORE OF KRILL EXTRACTS $(\bullet, \bigcirc)$ AND RESIDUES $(\boldsymbol{\bullet}, \triangle)$ PREPARED BY BOILING (CLOSED SYMBOLS) AND SUBCRITICAL WATER TREATMENT AT VARIOUS TEMPERATURES (OPEN SYMBOLS).

CAPITAL AND SMALL LABELS INDICATE THE SINIFICANT DIFFERENCE $(p<0.05)$ OF THE RESIDUE AND EXTRACT, RESPECTIVELY. 